\title{
Divide et Impera: Vertical and horizontal dimensions of British imperialism
}

Dr. Ilia Xypolia

Department of Politics and IR, University of Aberdeen, UK.

\begin{abstract}
:
This paper shifts the axis of analysis of imperialism and argues that the classic 'divide and rule' policy was implemented in a horizontal and vertical dimension simultaneously. By theorising Georg Simmel's classic triadic configurations, this paper explores whether in the British imperial strategy a divisive mechanism was set up within which inter-communal problems were exploited or an advantage was gained simply by being a tertius gaudens, i.e. a rejoicing third. This paper argues that the British Empire deliberately introduced a 'divide and rule' structure in order to gain an advantage in existing or emerging hostilities between the local communities.
\end{abstract}

Keywords: imperialism, divide and rule, nationalism, resistance, collaboration, path dependency

\section{Correspondence Address:}

Dr. Ilia Xypolia, Department of Politics and IR, University of Aberdeen, Edward Wright Building, Dunbar St., AB24 3QY, Aberdeen, United Kingdom.

Tel.: +44(o)1224272647

Mob: $+44($ o $) 7774446623$

E-mail: iliaxypolia@gmail.com and ilia.xypolia@abdn.ac.uk

\section{Note on contributor:}

Ilia Xypolia is a Research Fellow at University of Aberdeen and serves as the Reviews Editor for the Journal of Global Faultlines. She has previously worked at Keele University and the University of London. Her publications and ongoing research cover various aspects of the history and politics of the Eastern Mediterranean through a globalist perspective. 


\title{
Divide et Impera: \\ Vertical and horizontal dimensions of British imperialism
}

Ilia Xypolia

University of Aberdeen, UK.

\begin{abstract}
:
This paper shifts the axis of analysis of imperialism and argues that the classic 'divide and rule' policy was implemented in a horizontal and vertical dimension simultaneously. By theorising Georg Simmel's classic triadic configurations, this paper explores whether in the British imperial strategy a divisive mechanism was set up within which inter-communal problems were exploited or an advantage was gained simply by being a tertius gaudens, i.e. a rejoicing third. This paper argues that the British Empire deliberately introduced a 'divide and rule' structure in order to gain an advantage in existing or emerging hostilities between the local communities.
\end{abstract}

Keywords: imperialism, divide and rule, nationalism, resistance, collaboration, path dependency

In 1497 the explorer John Cabot was authorised by the English King Henry VII to 'subdue, occupy, and possess' any land he discovered. ${ }^{1}$ In 1578 the last monarch of the Tudor dynasty, Elizabeth I of England, granted a patent to an ambitious explorer, Humphrey Gilbert, for overseas exploration. Gilbert, in his second attempt ten years after the granting of the patent, reached the harbour of Newfoundland, which he formally claimed for England. The centuries that followed Gilbert's discovery saw the development of the largest empire in territorial and population terms in human history. The standard periodisation of the British Empire divides its history into two periods. The first period starts with the claiming of Newfoundland and lasts until the American Revolution. The second begins in the nineteenth century and continues until the official end of the empire a century later. For over three centuries the British ruled the seas, covering two fifths of the global territory and more than 450 million people during the heyday 
of British imperialism, from 1870 to 1914 . The empire reached its peak in the late nineteenth century during Queen Victoria's reign and ceased to exist shortly after the Second World War with the massive wave of decolonisation.

Since the fifteenth century, the British Empire had been expanding by assembling a vast variety of territories. It is only relatively recently that historical narratives of the British Empire attempted to give a comprehensive account of imperialism. ${ }^{2}$ Today Britain's imperial history is being illustrated by a variety of works that are trying to shed light on dark aspects of the empire. To the oft-quoted maxim used to refer to the British Empire, 'the sun never sets on the Empire', which stresses its extensive global imperial possessions, another came to be added and complemented it. This was the 'blood never dried' ${ }^{3}$ phrase first coined by the labour movement leader, Ernst Jones, which gave a fairer account of the empire and its practices.

The debates around which the contemporary historical accounts of the British Empire evolve mainly relate to the demarcation of the periods defining the first and the second British Empire, her extent, her motivation and driving force, the reasons for her decline and her legacy. However, probably the most controversial of the debates has been developed around the essence and the effects of imperialism.

The British Empire was the largest formal empire in world history, covering in its heyday over a quarter of the global population and territory. However, there is a growing consensus among historians that British imperialist influence was exerted not only on the territories shown in red on the world map but also on territories beyond formal imperial borders, such as Latin America, the Middle East and China. ${ }^{4}$

While it is easier for historians to reach a consensus on the demarcation of the formal British Empire, there still remains much controversy regarding British imperialism. British imperialism is an even more elusive and controversial term than the British Empire. 
The motivation behind the reasons for expanding or not expanding the empire could be insightful in terms of understanding the policies applied to the formally and informally ruled territories of the empire. The strategic imperatives of and competition between the European powers had been identified as the primary driving forces for the British imperial expansion during the Victorian era. ${ }^{5}$ When the empire was at the peak of its power, Halford Mackinder set out its twofold meaning for Britain. On the one hand, the federation of British commonwealths and, on the other, the maintenance of the British rule of foreign lands. Mackinder also underlined the economic benefits of the imperial assets. This financial aspect was essential to help fund the maintenance of a strong naval power. ${ }^{6}$

Accounts from John A. Hobson, Vladimir Lenin, and Rosa Luxemburg illustrate the economic factors that led to imperialism being portrayed purely as a product of capitalism. All of these scholars consider imperialism in terms of capitalistic development. They all view imperialism as characteristic of a certain aspect and phase of the capitalistic system. Their explanation of imperialism refers only to economic analysis. According to Marxist and Marxian scholars, imperialism as a political phenomenon should be understood as a direct reflection of economic forces. Within the same realm, liberal scholars such as Hobson adopt an economic explanation of imperialism, though they stress the maladjustments in the capitalist system at a global level.

It is important to consider the commercial and financial foundations of imperialism in order to sketch the motives for building the Empire. Economic historians Peter Cain and Antony Hopkins suggest that the main drive behind the imperial expansion was not geopolitical but financial. ${ }^{7}$ Cain and Hopkins, coining the term and the concept of 'gentlemanly capitalism', stress the significance of the financial sector of the British economy and state that it was the principal motive driving imperialism. 
Contrary to these economic analyses, Joseph A. Schumpeter's work aims to offer a historical and sociological analysis. His social analysis emphasises imperialist agents, or, as he prefers to call them, the 'warrior class'. He attempts to connect ancient imperial expansions' to the atavism of the imperialism of modern capitalist civilisation. ${ }^{8}$ Schumpeter defines imperialism as the object-less disposition on the part of a state to carry out unlimited forcible expansion, by force and without assigned limits. ${ }^{9}$ He disagrees with Lenin's view, because imperialism existed in the pre-capitalist era. In Schumpeter's theorisation of imperialism, all political units in history share the aspiration of territorial expansion. However, Schumpeter's view is problematic because he attributes imperialism to irrational elites. His argument runs in parallel with that of optimistic liberal scholars who see economic interdependence, trade and globalisation as leading to a Kantian perceptual peace. However, Schumpeter's view of imperialism focuses only on military expansion and omits economic expansion. This omission has been critiqued by Marxist and Marxian scholars. Scholars such as Giovanni Arrighi and Immanuel Wallerstein, who are researching dependency theory and world-system theory, stress the significance of economic imperialism. ${ }^{10}$

The realist scholar of international relations Hans Morgenthau considers that imperialism and imperialistic ambitions are indiscriminately applied by one country via its foreign policy, regardless of its actual character, to anything happening in another country with which it disagrees. ${ }^{11}$ Basing his conceptualisation on the balance-of-power notion, Morgenthau defines imperialism as a national foreign policy that aims to acquire more power by reversing the status quo.

Edward Said defines the term imperialism as 'the practice, the theory, and the attitudes of a dominating metropolitan center ruling a distant territory'. However, Said makes a sharp distinction between imperialism and colonialism. ${ }^{12} \mathrm{He}$ understands colonialism as a consequence of imperialism, that is, the implanting of settlements on distant territory. He 
highlights that even when colonialism has officially ended, imperialism has remained by being present in the general cultural spheres of a country and several political, ideological, economic and social practices. ${ }^{13}$

Michael Doyle, a prominent scholar of imperialism, considers empire as 'a relationship, formal or informal, in which one state controls the effective political sovereignty of another political society'. ${ }^{14}$ Doyle argues that an empire can be achieved by 'force, by political collaboration, by economic, social, or cultural dependence'. ${ }^{15}$ For Doyle, imperialism is simply the 'process or policy of establishing or maintaining an empire'. ${ }^{16}$

Theorising imperialism and empire has traditionally evolved through a Eurocentric understanding of world history. ${ }^{17}$ The historian Ronald Robinson was probably the first to highlight this bias in the historiography of the British Empire. Robinson's 'excentric' or collaborative theory of imperialism challenges Eurocentric theories of imperialism and suggests that the determinant factor of the incidence, the form, the rise and the fall of imperialism has been indigenous collaboration and resistance. ${ }^{18}$ For Robinson, the formal acquisition of territories was the result of local factors and the interactions between indigenous elites and European communities. Robinson's theory of collaboration on the periphery highlights the argument that the peripheral problems were the cause of imperial expansion. For Robinson, they are the sine qua non for the establishment of the formal empire. For example, British rule established a colony in India, where there were collaborators, while the British retained an informal empire in China and Japan, where there were no collaborators. Robinson highlights another important dimension, which is that when the collaborating ruling elite chooses resistance, a counter-elite opts out of collaboration. ${ }^{19}$ The collaboration mechanism has two levels. At the first level, there is an arrangement between the agents of industrial society and indigenous elites. At the second level, there is a collaboration between indigenous elites and the rigidities of local interests and institutions. ${ }^{20}$ 
The interplay between resistance and collaboration could be an explanatory dimension for the strategy that the British Empire adopted across its diverse territories. The British Empire was not rigid and her rule was readily capable of adapting to local dynamics and developments. The indigenous collaboration and resistance were constantly shaping and reshaping British colonial policies.

\section{Principles and methods of administration}

It is often believed that despite the immense diversity of territories and populations, remarkably consistent methods of administration were followed by European empires, with the French Empire applying a direct rule and the British Empire an indirect rule. ${ }^{21}$ This over-simplistic distinction certainly blurs the real dimensions and special characteristics that the model of administration had in relation to the extensive territories of the British Empire over a period of five centuries.

We can mark three phases of imperial rule according to the method of administration used. In the first phase, between the seventeenth century and the mid eighteenth century, the British conquered the New World and to a large extent its domination followed the direct rule model. The direct rule usually took the form of either a settler colony or a plantation colony. In the former, a significant number of Europeans were settled in the new colony and Britishstyle administrative institutions were established. In the latter, the established coercive plantation $^{22}$ system required a slave trade and resulted in institutionally enforced inequalities.

During the second phase, from 1750 to 1850, the British Empire expanded its territories into Asia and Australasia. In Australia (1788) and New Zealand (1841) a settler model of 
administration was established, while the coercive plantation system was applied in several colonies, the Bahamas (1717), Belize (1786), Mauritius (1810), Guyana (1814) and Trinidad and Tobago (1797). In South Africa, the British established a settler colony that initially controlled the Cape with a direct rule but later the colony was organised using an indirect rule form. The largest anti-imperial uprising that took place in India in 1857 is considered as a turning point in terms of the strategy and policy applied by the imperial rule. In the aftermath of the 1857 Indian Rebellion, the British Raj was established. The British, by declaring a policy of non-interference into Indian culture and tradition, proclaimed an indirectly ruled model of imperialism. The ruling system applied to the 'jewel in the crown of the British Empire' took the form of an indirect ruling system of domination in order to prevent further confrontations.

During the third and last phase, from the mid nineteenth century onwards, the British Empire spread its influence and possessions into Africa, the Middle East and the Pacific Ocean. In the aftermath of the 'scramble for Africa' indirect rule was established in Botswana (Bechuanaland Protectorate 1885), Gambia (1816), Ghana (Gold Coast 1821), Kenya (East Africa Protectorate 1895), Malawi (British Central Africa Protectorate 1889), Nigeria (1900), Sierra Leone (1896), Sudan (1899), Swaziland (1903), Tanzania (1919), Uganda (1894), Zambia (Northern Rhodesia 1890) and Zimbabwe (Southern Rhodesia 1890).

The indirect rule of the British Empire is often romanticised by nostalgic accounts of the empire. ${ }^{23}$ It was based on the principle of maximising the appropriation of resources. Although indirect rule was the hallmark of British imperialism, it was applied owing to necessity rather than any notion of liberal intentions. ${ }^{24}$ The global overextension of the British Empire and the consequent opposition of indigenous national movements necessitated the adoption of a less expensive and confrontational form of domination that would be based on indigenous collaboration. ${ }^{25}$ It was impossible to create and maintain a rule in the form of the plantation or the settlement model in all of the imperial possessions. Therefore, the imperial 
strategy eventually evolved to take the form of an indirect rule in which imperial domination was dependent on collaboration with the indigenous intermediaries. ${ }^{26}$ In relation to indirectly ruled colonies, the British ruled by incorporating existing indigenous political structures established by only a small number of British colonial administrators at the top of the administrative hierarchical structure.

The territories of the empire were shielded by the world's largest army. ${ }^{27}$ However, the bulk of workforce in the military forces and the colonial services was consisted of local indigenous people. ${ }^{28} \mathrm{~A}$ hierarchical bureaucracy was administering the empire, but the cost of this administration was mainly paid for from the taxation of the indigenous populations. ${ }^{29}$

\section{Divide et impera}

The Earl of Cromer suggested in 1910 that the problem British Empire would face in the future was the extent to which 'some 350 millions of Britons subjects, who are aliens to us in race, religion, language, manners, and customs, are to govern themselves, or are to be governed by us ${ }^{30}$ During the late Victorian period when there were many imperial scholars, an increasing number of those studying the British Empire were drawing an analogy between British imperialism and Roman imperialism. For the Earl of Cromer, the driving force that motivated both empires was the same: 'the imperious and irresistible necessity of acquiring defensible frontiers'. ${ }^{31}$ The methods of imperialism used in ancient and modern types of empires were very similar. Their undaunted audacity was largely aided by auxiliaries drawn from the conquered territories. ${ }^{32}$ 
British rule was certainly to a large extent based upon dividing the local population. Therefore, the empire de facto benefited from the hostile and rivalrous relations between two communities. The important question here is whether it set up a divisive mechanism through which any inter-communal problems would be exploited or an advantage was gained by simply being a tertius gaudens. Tertius gaudens literally means a rejoicing third that is, a party that benefits from a conflict between two other parties.

The 'divide and rule' strategy has been described as an essential feature of imperial policies. ${ }^{33}$ British rulers adopted the 'divide and rule' policy allied to territorial separation through segregation and partition. ${ }^{34}$ The imperial governments divided populations into distinct groups on the basis of linguistics, religion, ethnicity and race. ${ }^{35}$

The 'divide and rule' axiom has often been applied elusively and incorrectly in various policies and strategies. Nevertheless, the oft-quoted maxim of 'divide et impera' is a placeholder for a "complex of ideas related by a family resemblance, but differing in the details, mechanism and implications'. ${ }^{36}$ Posner suggests that the 'divide et impera' mechanism should have two conditions. The first one should be the inclusion of a unitary actor that bargains with or competes against a set of multiple actors. The second should be that the unitary actor follows an intentional strategy of exploiting problems of coordination or collective action among the multiple actors. ${ }^{37}$

Here we shall define 'divide and rule' as the mechanism in which the main feature is that a single actor exploits coordination problems among a group by making discriminatory offers or discriminatory threats. ${ }^{38}$ The relations between the British government and the main native communities were invariably asymmetric.

The eminent German sociologist Georg Simmel ${ }^{39}$, who discusses the diverse forms of social interaction, pioneered the study of triads, a group of three entities. ${ }^{40}$ In the combination 
of three elements characterised by an existing or emerging conflict between two, from which the third drew its advantage, the third party would have acted either as a tertius gaudens or as an imperialist. ${ }^{41}$ The advantage that the third party gains is only the result of the actions of the two conflicting parties. ${ }^{42}$

In the 'divide and rule' combination of Simmel's Triad, 'the third element intentionally produces the conflict in order to gain a dominating position' ${ }^{43}$ In this formation, the two parties are initially united or mutually dependent in regard to a third. ${ }^{44}$ The third party is also aware of how to distract the forces combined against it into action against each another. The outcome of a 'divide and rule' stance of the third party is that the 'two either keep each other balanced so that he, who is not interfered with by either, can pursue his advantages; or that they so weaken one another that neither of them stand up against his superiority'. ${ }^{45}$ This second type of triadic social formation existed in the vast majority of indirectly ruled colonies. The British government deliberately set up a 'divide and rule' structure in order to take advantage of the existing and emerging hostilities between the communities of the native population. The collaboration of the local native elites gave another dimension to the 'divide and rule' policies - a horizontal one. Therefore, the 'divide and rule' policy can be applied in two different ways. The first is where the foreign ruler divides the local population vertically, separating it into distinct communities, usually along religious, racial or linguistic lines. The second has a horizontal dimension because it occurs when the foreign rule divides the whole population or one community along class lines, thus separating the elites from the masses. The foreign ruler often divides a community or the whole population into a collaborating ruling elite and a resisting mass. The two different methods usually operate in complementary manner. Hence, the 'divide and rule' policy can operate both in a vertical way and in a horizontal way.

The Machiavellian method of 'dividing and ruling' the population through fostering hostility among the members of different ethnic, racial or religious communities was used in 
the vast majority of the British territories. However, the British Empire was not a monolithic entity and its grand strategy has always followed the fundamental principle of adaptability. According to the Chinese pioneer strategist Sun Tzu, a vital principle for a successful strategy is its adaptability to the relevant circumstances. ${ }^{46}$ Sun Tzu considers the art of studying circumstances as the most crucial element in terms of the final outcome. The variety of possible circumstances is infinite and the methods always have to be regulated by the consideration of these circumstances. As we analysed in depth above, the British were constantly adjusting their methods to fit with new conditions. It was part of reading new circumstances. They availed themselves of the opportunities that new circumstances provided.

\section{Path dependence}

In the aftermath of the Second World War, the massive wave of decolonisation meant that there was a new political map, and the majority of newly independent states soon found themselves in political and economic turmoil. The close ties of the former imperial territories with London were not fully broken after they were granted the status of separate sovereign states. ${ }^{47}$ The counter-insurgency wars of the British Empire against national liberation movements included brutal suppression of uprisings, with the Mau Mau case standing as the worst example of savagely violent campaigns. The notorious case of 'migrated archives' record series is indicative of British attempts to conceal imperial atrocities. ${ }^{48}$

The imperial heritage of community-based territorial separation is continuing to have an impact on post-colonial conflicts that were triggered by centralisation policies. ${ }^{49}$ Ongoing political conflicts in the empire's former territories derive from British separation policies. One 
of the significant political legacies of imperialism was the politicisation of cultural differences, which was achieved by turning them into the bases of discrimination. ${ }^{50}$

Development theories have mainly been divided into two approaches: modernisation and dependency. In the modernisation approach, the main emphasis is on the positive role of empires in securing peace and external defence policies ${ }^{51}$ and encouraging international trade and the movement of capital. ${ }^{52}$ Often this approach is preferred by apologists for the empire, who consider that British imperialism was a necessary evil that allowed free trade. These accounts indicate that free trade might have been mutually beneficial for both parties but that its gains were asymmetrical. They therefore tend to view the gains of free trade as a positivesum game and not a zero-sum game. However, an increasing number of scholars who support a structural dependency approach are currently researching to trace the imperial roots of today's uneven global development. Dependency theorists have attempted to trace the negative effects of imperial rule on development that has been caused by the excessive exploitation of colonies, the draining of resources or the emergence of a 'dependency' tie. ${ }^{53}$

The varied experiences of imperial rule have had a long-term impact on economic development. ${ }^{54}$ Lange argues that the states that experienced direct British rule have developed more successfully than those that were ruled indirectly. Many scholars have praised the positive impact of plantations, such as the opening up of land, the injection of productive and social overhead capital leading to more output and income, the introduction of new technology and the demonstration of new methods of production and modes of consumption to those whom the British Empire considered peasants. However, there are inherent factors in the plantation system that have been an impediment to development and that contribute to the persistence of underdevelopment. According to Beckford, the plantations brought a transformation from a condition of 'undevelopment' to the one of underdevelopment. ${ }^{55}$ At the same realm, Nicos Poulantzas emphasises the role of imperialism in the rise of the "comprador" bourgeoisie in the 
postcolonial states. According to Poulantzas, the interests of this comprador bourgeoisie have been "constitutively" linked to foreign imperialist capital. ${ }^{56}$

\section{Conclusion}

This paper has presented theoretical reasons and some empirical evidence to suggest that the 'divide and rule' strategy that has been an essential feature of imperial policies has not only divided territories and populations along racial, religious and linguistic lines but has also divided communities into a collaborating ruling elite and a resisting mass. By shifting the axis of analysis, this paper has argued that the classic 'divide and rule' policy was implemented in a horizontal and vertical dimension simultaneously. Theorising Georg Simmel's classic triadic configurations, this paper has explored whether in the British imperial strategy a divisive mechanism was set up in which inter-communal problems would be exploited or an advantage would be gained simply by being a tertius gaudens, that is, that the benefits would only be the result of the actions of the two conflicting parties. This paper argues that the British Empire deliberately set up a 'divide and rule' structure in order to take advantage of existing or emerging hostilities between the communities of the native population. In this structure the local elites played the most consequential role as their collaboration or resistance was constantly shaping and reshaping imperial policies. Hence, while the British imperial rule recurrently adopted the vertical 'divide and rule' policy that promoted territorial separation through segregation and partition by dividing populations into distinct groups on the basis of linguistics, religion, ethnicity and race, the collaboration of local native elites gave another dimension to the 'divide and rule' policies - a horizontal one. Therefore, the 'divide and rule' policy can be applied in two different ways. The first is where the foreign ruler divides the 
local population vertically, separating it into distinct communities, usually along religious, racial or linguistic lines. The second has a horizontal dimension because it occurs when the foreign rule divides the whole population or a community along class lines, thus separating the elites from the masses. These two ways usually operated in a complementary fashion. By examining this little-covered dimension of imperialism, this paper has aimed to increase the understanding of the background to some of today's most intractable issues.

\section{Bibliography:}

Balfour-Paul, G., 2001. Britain's Informal Empire in the Middle East. In J. Brown \& W. R. Louis, eds. The Oxford History of the British Empire IV: The Twentieth Century. Oxford: Oxford University Press.

Beckford, G.L., 1972. Persistent Poverty: Underdevelopment in Plantation Economies of the Third World, Oxford: Oxford University Press.

Cain, P.J. \& Hopkins, A.G., 2002. British Imperialism, 1688 - 2000. 2nd ed., Harlow, UK: Pearson.

Caplow, T. 1968. Two against one: coalitions in triads. Englewood Cliffs, N.J: Prentice-Hall.

Christopher, A.J., 1988. Divide and Rule': The Impress of British Separation Policies. Area, 20(3), pp.233-240.

Christopher, A.J., 2002. Decolonisation without independence. GeoJournal, 53(1), pp.213224.

Cromer, E. of, 1910. Ancient and Modern Imperialism, London: John Murray.

Nicholas B. Dirks, Castes of Mind: Colonialism and the Making of Modern India. Princeton, NJ, 2001.

Evans, E.W., 1950. Principles and Methods of Administration in the British Colonial Empire. In C. M. Macinnes, ed. Principles and Methods of Colonial Administration. London: Buttersworths Scientific Publications.

Ferguson, N., 2002. Empire: How Britain Made the Modern World, London: Penguin Books. 
Fouskas, V. K and Gökay, B., 2005. The New American Imperialism: Bush's War on Terror and Blood for Oil. Westport, CT: Praeger.

Fouskas, V. K. and Gökay, B., 2012. The Fall of the US Empire: Global Fault-Lines and the Shifting Imperial Order. London: Pluto.

Frank, A.G., 1978. Dependent Accumulation and Underdevelopment, New York: Monthly Review Press.

Frisby, D. 1994. Georg Simmel: Critical Assessments. London: Routledge.

Johnson, R., 2003. British Imperialism, Basingstoke, Hampshire: Palgrave MacMillan.

Jones, W.O., 1968. Plantations. In D. S. Sills, ed. International Encyclopaedia of Social Sciences. New York: The Free Press.

Kadushin, C. 2012. Understanding Social Networks: Theories, Concepts, and Findings. Oxford: Oxford University Press.

Lal, D., 2004. In Praise of Empires: Globalisation and Order, London: Palgrave.

Lange, M., 2009. Lineages of Despotism and Development: British Colonialism and State Power, Chicago, IL: University of Chicago Press.

Langer, W., 1951. The Diplomacy of Imperialism 1890-1902, New York: Alfred A. Knopf.

Mackinder, H., 1902. Britain and the British Seas, London: William Heinemann.

Mamdami, M., 2012. Define and Rule: Native as Political Identity, Cambridge, MA: Harvard University Press.

Mill, J. S. 1999. On Liberty. London: Longmans, Green, Reader and Dyer.

Morrock, R., 1973. Heritage of Strife - Effects of Colonialist Divide and Rule Strategy Upon Colonized Peoples. Science \& Society, 37(2), pp.129-151.

Newsinger, J., 2006. The Blood Never Dried: A People's History of the British Empire, London: Bookmarks Publications.

Porter, B., 2004. The lion's share: a short history of British imperialism, 1859-2004. 4th ed., Harlow, UK: Pearson.

Posner, E.A., Spier, K.E. \& Vernrule, A., 2010. Divide and Conquer. Journal of Legal Analysis, 2(2), pp.417-471.

Poulantzas, N., 1973. On Social Classes. New Left Review, 78 (March-April), pp. 27-54.

Pyyhtinen, O., 2010. Simmel and 'the Social'. London: Palgrave Macmillan. 
Robinson, R., 1972. Non-European Foundations of European Imperialism: Sketch for a Theory of Collaboration. In E. R. J. Owen \& R. B. Sutcliffe, eds. Studies in the Theory of Imperialism. London: Longman.

Rossides, D. W. 1998. Social Theory: Its Origins, History, and Contemporary Relevance. New York, NY: Rowman \& Littlefield.

Schermer, H. and Jary, D. 2013. Form and Dialectic in Georg Simmel's Sociology: A New Interpretation. London: Palgrave Macmillan.

Simmel, G., 1950. The Sociology of Georg Simmel, Glencoe, Illinois: The Free Press.

Simmons, J., 1960. From Empire to Commonwealth. Principles of British Imperial Government, London: Odhams Press.

Sullivan, E. P., 1983. Liberalism and Imperialism: J. S. Mill's Defence of the British Empire. Journal of the History of Ideas, 44(4), pp. 599-617.

Taylor, A.J., 1954. The struggle for Mastery in Europe: 1848-1918, Oxford: Oxford University Press.

Tzu, S., 2002. The Art of War, London: Penguin Books.

Xypolia, I., 2016. Eurocentrism and Orientalism. in S Ray et al (eds.) Blackwell Encyclopedia of Postcolonial Studies. New Jersey: Wiley-Blackwell.

Xypolia, I., 2016. Cultural Propaganda and Plans for a British University in the Middle East. Mediterranean Quarterly, 27(3).

Xypolia, I., 2016. From Mare Nostrum to Insula Nostra: British Colonial Cyprus and the Italian Imperial Threat. The Round Table: The Commonwealth Journal of International Affairs, 105(3), pp. 287-296.

\footnotetext{
${ }^{1}$ Simmons, J. (ed.) (1960) From Empire to Commonwealth. Principles of British Imperial Government. Odhams Press: London. Page 35.

2 Porter, B. (2004) The lion's share: a short history of British imperialism, 1859-2004. 4th edition. Pearson Itd: Harlow, UK. Page ix.

${ }^{3}$ Newsinger, J. (2006) The Blood Never Dried: A People's History of the British Empire. London: Bookmarks Publications.
} 
${ }^{4}$ Johnson, R. (2003) British Imperialism. Basingstoke, UK: Palgrave MacMillan. page 1.; Balfour-Paul, G. (2001) 'Britain's Informal Empire in the Middle East', in Judith M. Brown and Louis, (eds.) The Oxford History of the British Empire IV The Twentieth Century. Oxford: Oxford University Press.

${ }^{5}$ Taylor, A.J. (1954) The struggle for Mastery in Europe: 1848-1918. Oxford: Oxford University Press; Langer, W. L. (1951) The Diplomacy of Imperialism. New York: Alfred A. Knopf.

${ }^{6}$ Mackinder, H. (1902) Britain and the British Seas. London: William Heinemann. Pp. 345-346.

${ }^{7}$ Cain, P. J. and Hopkins, A. G. (2002) British Imperialism, $1688-2000.2^{\text {nd }}$ edition. Harlow, Essex: Pearson Education.

${ }^{8}$ Schumpeter, J. A. (1966) Imperialism \& Social Classes: Two essays by Joseph Schumpeter, 9th edn. New York: Meridian Books. page vii.

${ }^{9}$ Schumpeter, J. A. (1966) Imperialism \& Social Classes: Two essays by Joseph Schumpeter, 9th edn. New York: Meridian Books. page 6.

${ }^{10}$ For a brief account of the Marxian take on imperialism and neo-imperialism, see V. K. Fouskas and B. Gökay, The New American Imperialism: Bush's War on Terror and Blood for Oil (Westport, CT: Praeger, 2005); V. K.

Fouskas \& B. Gökay, The Fall of the US Empire: Global Fault-Lines and the Shifting Imperial Order (London: Pluto, 2012).

${ }^{11}$ Morgenthau, H. J. (1960) Politics Among Nations, 3rd ed. New York: Alfred A. Knopf. page 45.

12 Said, E. W. (1994) Culture and Imperialism. New York: Vintage Books. Page 9.

13 Ibid p.9.

${ }^{14}$ Doyle, M. W. (1986) Empires. Ithaca, NY: Cornell University Press. Page 45.

15 Ibid p.45.

16 Ibid p.45.

${ }^{17}$ I. Xypolia, 'Eurocentrism and Orientalism'. in S Ray et al (eds), (Blackwell Encyclopedia of Postcolonial Studies. New Jersey: Wiley-Blackwell, 2016).

18 Robinson, R. (1972) 'Non-European Foundations of European Imperialism: Sketch for a Theory of Collaboration' in E. R. J. Owen and R.B. Sutcliffe, (eds.) Studies in the Theory of Imperialism. London: Longman. Page 229.

19 ibid page 120 .

20 ibid page 121.

${ }^{21}$ Evans, E. W. (1950) 'Principles and Methods of Administration in the British Colonial Empire', in C.M.

Macinnes, Principles and Methods of Colonial Administration. London: Buttersworths Scientific Publications. pp. 9-19.

${ }^{22}$ According to Jones' definition: 'A plantation is an economic unit producing agricultural commodities (field crops or horticultural products, but not livestock) for sale and employing a relatively large number of unskilled laborers whose activities are closely supervised. Plantations usually employ a year-round labor crew of some size, and they usually specialize in the production of only one or two marketable products. They differ from other kinds of farms in the way in which the factors of productions, primarily management and labor, are combined.' Jones, W. O. (1968) 'Plantations' in David L. Sills (ed.) International Encyclopaedia of Social Sciences, 12, p. 154.

${ }^{23}$ Ferguson, N. (2002) Empire: How Britain Made the Modern World. London: Penguin Books.

${ }^{24}$ John Stuart Mill work epitomises the self-contradictions of the British liberal theory. While the work of Adam Smith, Jeremy Bentham and James Mill has been associated with an anti-imperialist argument from a political economy perspective in the 19th century, the influential work of John Stuart Mill incorporated the sophisticated defence of the expansion of the British Empire. Mill, J. S. 1999. On Liberty. London: Longmans, Green, Reader and Dyer. For more see, Eileen P. Sullivan (1983) Liberalism and Imperialism: J. S. Mill's Defence of the British Empire. Journal of the History of Ideas, 44(4): 599-617. Page 617.

${ }^{25}$ I. Xypolia, (2016_in press). 'Cultural Propaganda and Plans for a British University in the Middle East'.

Mediterranean Quarterly, vol 27, no. 3.

${ }^{26}$ I. Xypolia, (2016). 'From Mare Nostrum to Insula Nostra: British Colonial Cyprus and the Italian Imperial Threat'. The Round Table: The Commonwealth Journal of International Affairs, vol 105, no. 3, pp. 287-296.

27 Johnson R. (2003) British Imperialism. Basingstoke, Hampshire, UK: Palgrave MacMillan. Page 4.

28 Ibid page 6.

${ }^{29}$ Ibid page 5.

${ }^{30}$ Cromer, E. (1910) Ancient and Modern Imperialism. London: John Murray Publishers. Pages 18-19.

${ }^{31}$ ibid pages 19-20.

32 ibid pages 34-35. 
${ }_{33}$ Morrock, R. (1973) Heritage of Strife - Effects of Colonialist Divide and Rule Strategy Upon Colonized Peoples. Science \& Society. 37(2): 129- 151.

${ }^{34}$ Christopher, A. J. (1988), 'Divide and Rule': The Impress of British Separation Policies', Area, 20 (3), pp.233240, page 233.

35 Ibid

${ }^{36}$ Posner, E. A., Spier, K. E. and Vernrule, A. (2010) 'Divide and Conquer', Journal of Legal Analysis, 2(2): 417471.

37 ibid page 419.

38 ibid page 418

${ }^{39}$ For more on Simmel, see Rossides, D. W. 1998. Social Theory: Its Origins, History, and Contemporary Relevance. New York, NY: Rowman \& Littlefield; Kadushin, C. 2012. Understanding Social Networks: Theories, Concepts, and Findings. Oxford: Oxford University Press; Frisby, D. 1994. Georg Simmel: Critical Assessments. London: Routledge; Caplow, T. 1968. Two against one: coalitions in triads. Englewood Cliffs, N.J: Prentice-Hall. ${ }^{40}$ Simmel, G. (1950) The Sociology of Georg Simmel, (translated, edited and with an introduction by Kurth $\mathrm{H}$. Wolf), Glencoe, Illinois: The Free Press. Page 163. The advantage occurring to the tertius derived from the fact that he has an equal, equally independent, and for this very reason decisive, relation to two others. The advantage, however, does not exclusively depend on the hostility of the two. A certain general differentiation, mutual strangeness, or qualitative dualism may be sufficient. This, in fact, is the basic formula of the type, and the hostility of the elements is merely a specific case of it, even if it is the most common. (page 159) Simmel gives the example of the Catholic Church since the Middle Ages among secular powers, as a tertius gaudens. ${ }^{41}$ Schermer, H. and Jary, D. 2013. Form and Dialectic in Georg Simmel's Sociology: A New Interpretation. London: Palgrave Macmillan.

42 ibid pages 154-155.

43 ibid page 163.

${ }^{44}$ Pyyhtinen, O., 2010. Simmel and 'the Social'. London: Palgrave Macmillan.

${ }^{45}$ Simmel, G. (1950) The Sociology of Georg Simmel, (translated, edited and with an introduction by Kurth $\mathrm{H}$. Wolf), Glencoe, Illinois: The Free Press. Page 163.

${ }^{46}$ Tzu, S. (2002) The Art of War. London: Penguin Books.

${ }^{47}$ Christopher, A. J. (2002) 'Decolonisation without independence', GeoJournal, 56(1): 213-224

${ }^{48}$ For more see: Howe, S. (2011) 'Flakking the Mau Mau Catchers', The Journal of Imperial and Commonwealth History. 39(5):695-697.

${ }^{49}$ Christopher, A. J. (1992) 'Urban Segregation Levels in the British Overseas Empire and Its Successors in the Twentieth Century', Transactions of the Institute of British Geographers. 17 (1): 95-107.

${ }^{50}$ Mamdami, M. (2012) Define and Rule: Native as Political Identity. Cambridge, MA: Harvard University Press.

${ }^{51}$ Lal, D. (2004) In Praise of Empires: Globalisation and Order. London: Palgrave.

52 Ferguson, N. (2002) Empire: How Britain Made the Modern World. London: Penguin Books.

53 See Frank, A. G. (1978) Dependent Accumulation and Underdevelopment. New York: Monthly Review Press.

${ }^{54}$ Lange, M. (2009) Lineages of Despotism and Development: British Colonialism and State Power. Chicago, IL: University of Chicago Press.

${ }^{55}$ Beckford, G. L. (1972) Persistent Poverty: Underdevelopment in Plantation Economies of the Third World. Oxford: Oxford University Press. Page 210.

${ }^{56}$ N. Poulantzas, On Social Classes. New Left Review, 78 (March-April 1973) 27-54. 